\title{
ANALISIS PERBEDAAN KEPUASAN KONSUMEN TERHADAP PEMBELIAN PRODUK BAJU SECARA ONLINE DAN OFFLINE
}

\author{
Dewi Nuraini \\ Fakultas Ekonomi dan Bisnis, Universitas Wijaya Kusuma Surabaya \\ email: dewintanada@gmail.com \\ Evianah \\ Fakultas Ekonomi dan Bisnis, Universitas Wijaya Kusuma Surabaya \\ email: evianah@gmail.com
}

\begin{abstract}
This study aims to compare differences in customer satisfaction with the purchase of clothing products online and offline (studies on consumers online and offline in Surabaya). The sample in this study was divided into two different respondents, namely 75 respondents who bought clothes online and 75 respondents who made offline purchase of clothing products. Whereas to test the questionaire in this study must fulfill two important requirements that apply to a quastionnaire that is valid and reliable, for this reason, validitity and reliability test are used, and to answer the hypothesis proposed in this study using the Indpendent T Test statistical tool. From the result of research conducted on 75 respondents who made online purchase and 75 respondents who made offline purchase for clothing products, there were significant differences in customer satisfaction when cunsumers made purchase online and offline. This can be seen from the results of the mean for respondent satisfation online which equal to 3,997, the value is lower than the mean satisfaction of respondent offline of 4,387. This mean that consumer satisfaction of buying offline is higher than consumer satisfaction of buying online.
\end{abstract}

Keywords: customer satisfaction, product quality, service quality, price, emotion, cost

\section{PENDAHULUAN}

Jumlah pengguna internet di dunia semakin tumbuh pesat yang membuat kegiatan perdagangan dan bisnis melalui internet ini semakin banyak digunakan oleh orang-orang, yang dikenal dengan nama $e$-commerce.

Internet marketing merupakan bagian dari pemasaran langsung yang memungkinkan konsumen untuk mencari penjual dalam menemukan produk dan harga terbaik untuk memenuhi kebutuhan mereka. Internet marketing memberikan kesempatan bagi pemasar untuk berinteraksi dan membantu perusahaan dalam menarik perhatian pelanggan.

Berbelanja merupakan salah satu kegiatan yang berkembang di masyarakat terutama di kalangan perkotaan. Berbelanja juga telah menjadi fenomena yang wajib untuk dilakukan bagi sebagian konsumen. Perkembangan gaya berbelanja pun berubah seiring jaman, di mana konsumen tidak harus dating ke toko untuk berbelanja namun sekarang ini, orang dapat menemukan dua format dasar ketika berbelanja yaitu: belanja di toko dan belanja di non-toko (online). Internet menyediakan peluang kepada pemasar dan konsumen untuk interaksi dan individualisasi yang jauh lebih besar (Kotler dan Keller, 2009).

Di jaman yang serba canggih sekarang ini sudah banyak toko online yang berjamuran dimana-mana, berbagai jenis barang dijual melalui online shop, karena memang penjualan online shop ini tergolong unik dan mudah, tidak harus capekcapek, tinggal nongkrong didepan komputer dan pilih barang lalu transfer. Namun meski banyak berjamuran online shop, dari tahun ke tahun toko offline seperti mall, suparmarket dan pusat perbelanjaan banyak juga berdiri.

Pada dasarnya belanja online dengan belanja offline memiliki kesamaan yaitu sama-sama membeli suatu produk. Cuma yang membedakan adalah dari segi cara membelinya. Memilih belanja online atau offline semuanya memiliki kelebihan dan kekurangan masing-masing. Belanja offline mengharuskan kita datang kangsung ke penjual, hal tersebut bagi seseorang yang sibuk dan tidak mempunyai banyak waktu akan menyulitkan bagi mereka. Sehingga pilihan belanja online menjadi salah satu alternatif pilihannya.Alternatif pilhan 
belanja online dan offline memberikan perbedaan tersendiri bagi konsumen terutama menyangkut kepuasan konsumen itu sendiri.

Sebuah isu yang menarik bagi praktisi dan akademisi dalam menentukan apakah terdapat perbedaan yang sistematis mengenai perilaku pilihan konsumen ketika berbelanja antara online atau offline. Setiap orang akan menunjukkan pilihan perilaku yang berbeda ketika mereka berbelanja secara online maupun offline, hal ini penting bagi pemasar online untuk mengidentifikasi dan memahami perbedaan dalam perilaku belanja online dan offline ini ketika merumuskan strategi pemasaran yang nanatinya dapat berdampak terhadap kepuasan konsumen. (Degeratu, Rangaswamy, dan Wu, 2001).

\section{Pemasaran Online dan Pemasaran Offline}

Menurut Detik.com (2008), definisi pemasaran online pada dasarnya adalah kegiatan komunikasi pemasaran dengan menggunakan media internet. Sedangakan pemasaran offline adalah proses transaksi penjualan barang dan jasa secara langsung yang dimana produsen dan konsumen bertemu dan terjadinya proses transaksi jual beli.

Bisnis online dan offline memiliki banyak perbedaan, khususnya dalam kegiatan pemasarannya. Bisnis online dinilai memiliki biaya lebih murah dalam pemasaran dan promosinya, jadi bisa dibilang modalnya lebih terjangkau dibanding dengan kegiatan offline yang butuh modal besar. Akan tetapi, ternyata yang membedakan bisnis offline dan online tidak hanya dibedakan dari pemasarannya saja, tetapi juga target konsumen pemasarannya. Berikut adalah perbedaannya:

(https://www.jurnal.id/id/blog/2018-mengenal-4perbedaan-target-konsumen-pemasaran-online-

dan-offline/).

1. Jangkauan

Target konsumen pemasaran online dan offline memiliki jangkauan berbeda-beda, berikut ini penjelasannya:

Offline: Untuk menjual suatu produk biasanya konsumen yang butuh produk datang ke toko. Umumnya, toko offline hanya bisa melayani konsumen pada daerah tertentu saja. Untuk menarik konsumen, toko offline yang kecil akan membagikan brosur kepada calon konsumen.

Online: dikarenakan strategi pemasaran dilakukan secara online menggunakan digital marketing, jadi jangkauan konsumen onlinelebih luas dibanding offline. Bahkan, untuk bisnis online ini konsumennya bisa mencapai luar kota atau bahkan luar pulau. Sehingga kesempatan untuk memperoleh keuntungan juga lebih besar.

2. Strategi Pemasaran

Baik bisnis online maupun offline memiliki target konsumen pemasaran yang berbeda berdasarkan strategi yang digunakan:

Offline: strategi pemasaran yang dilakukan untuk menarik target konsumen adalah dengan membuat spanduk di sekitar toko atau bisa juga dengan membagikan brosur. Untuk toko yang besar ia bisa menggunakan televisi ataupun radio. Namun, sekali lagi orang-orang yang mengunjungi toko tersebut hanya masyarakat yang berada di daerah sekitarnya.

Online: strategi pemasaran online yang digunakan untuk mencapai target konsumen pemasaran online dengan menggunakan SEO (Search Engine Optimization), SEM (Search Engine Marketing) dan social media. Jadi, cakupan untuk memilih pelanggan lebih luas dan lebih spesifik.

3. Pengenalan Brand

Untuk bisnis online dan offline target konsumen pemasarannya juga bisa dibedakan dengan pengenalan brand:

Offline: konsumen yang membeli ke toko offline umumnya karena toko tersebut sudah tepercaya. Mereka tidak mau mengambil risiko untuk membeli di toko yang belum terkenal atau tepercaya. Dengan adanya hal tersebut, membuat toko offline selalu membutuhkan promosi besar secara berkesinambungan agar orang-orang mengenal produk mereka.

Online: berbeda dengan offline, untuk target konsumen pemasaran ini mereka yang membeli di toko online umumnya tidak terlalu peduli dengan brand. Konsumen lebih mengutamakan harga terjangkau. Terutama dengan keberadaan marketplace yang tepercaya, sehingga kerja sama dengan sebuah marketplace akan sangat membantu.

4. Customer Experience

Selanjutnya yang membedakan target konsumen pemasaran online dan offline adalah customer experience-nya.

Offline: jika suatu produk memiliki harga terjangkau dan kualitas yang bagus umumnya akan berdampak secara individual terhadap konsumen dengan menjadi pelanggan yang setia. Namun, jika konsumen memiliki pengalaman pelayanan yang baik dari toko tersebut nantinya akan ada dampak promosi 
positif yang didapat dari pengalaman mereka dan disebarkan dari mulut ke mulut. Namun, jangkauannya lebih sempit karena biasanya hanya pada orang-orang terdekat di sekitarnya.

Online: untuk bisnis online, konsumen yang puas terhadap pelayanan di toko online tersebut, akan memberikan review secara langsung melalui kolom review maupun komentar sehingga bisa berdampak secara langsung pada pelanggan baru yang melihat review yang diberikan.

\section{Keputusan Pembelian}

Keputusan pembelian konsumen terhadap suatu produk pada dasarnya erat kaitannya dengan perilaku konsumen. Perilaku konsumen merupakan unsur penting dalam kegiatan pemasaran suatu produk yang perlu diketahui oleh perusahaan, karena perusahaan pada dasarnya tidak mengetahui mengenai apa yang ada dalam pikiran seorang konsumen pada waktu sebelum, sedang, dan setelah melakukan pembelian produk tersebut.

Keputusan pembelian merupakan suatu proses pengambilan keputusan akan pembelian yang mencakup penentuan apa yang akan dibeli atau tidak melakukan pembelian dan keputusan itu diperoleh dari kegiatan-kegiatan sebelumnya (Assauri, 2004). Menurut Kotler (2000) ada lima tahap dalam proses keputusan pembelian yaitu:

1. Pengenalan kebutuhan

Proses pembelian dimulai saat pembeli mengenali sebuah masalah atau kebutuhan. Pembeli merasakan perbedaan antara keadaan aktualnya dengan keadaan yang diinginkannya.

2. Pencarian Informasi

Evaluasi alternatif merupakan proses dimana suatu alternatif pilihan disesuaikan dan dipilih untuk memenuhi kebutuhan konsumen.

3. Keputusan Pembelian

Keputusan untuk membeli di sini merupakan proses dalam pembelian yang nyata. Jadi, setelah tahap-tahap di muka dilakukan, maka konsumen harus mengambil keputusan apakah membeli atau tidak.

4. Perilaku Pasca Pembelian

Tugas pemasar tidak berakhir saat produk dibeli, melainkan berlanjut hingga periode pasca pembelian. Setelah pembelian produk terjadi, konsumen akan mengalami suatu tingkat kepuasan atau ketidakpuasan. Kepuasan atau ketidakpuasan pembeli terhadap produk akan mempengaruhi tingkah laku berikutnya. Konsumen yang merasa puas akan memperlihatkan peluang membeli yang lebih tinggi dalam kesempatan berikutnya. Konsumen yang merasa puas akan cenderung mengatakan sesuatu yang serba baik tentang produk yang bersangkutan kepada orang lain. Apabila konsumen dalam melakukan pembelian tidak merasa puas dengan produk yang telah dibelinya, ada dua kemungkinan yang akan dilakukan oleh konsumen. Pertama, dengan meninggalkan atau konsumen tidak mau melakukan pembelian ulang. Kedua, ia akan mencari informasi tambahan mengenai produk yang telah dibelinya untuk menguatkan pendiriannya mengapa ia memilih produk itu sehingga ketidakpuasan tersebut dapat dikurangi.

\section{Kepuasan Konsumen}

Kepuasan Konsumen yaitu Sejauh mana anggapan kinerja produk memenuhi harapan pembeli. Faktor-faktor yang mempengaruhi kepuasan konsumen (Lupyoadi, 2001):

1. Kualitas produk, yaitu pelanggan akan merasa puas bila hasil mereka menunjukkan bahwa produk yang mereka gunakan berkualitas.

2. Kualitas pelayanan, yaitu pelanggan akan merasa puas bila mereka mendapatkan pelayanan yang baik atau sesuai dengan yang diharapkan.

3. Emosi, yaitu pelanggan akan merasa bangga dan mendapatkan keyakinan bahwa orang lain akan kagum terhadap dia bila menggunakan produk dengan merek tertentu yang cenderung mempunyai tingkat kepuasan yang lebih tinggi.

4. Harga, yaitu produk yang mempunyai kualitas yang sama tetapi menetapkan harga yang relatif murah akan memberikan nilai yang lebih tinggi kepada pelanggan.

5. Biaya, yaitu pelanggan yang tidak perlu mengeluarkan biaya tambahan atau tidak perlu membuang waktu untuk mendapatkan suatu produk tersebut.

\section{METODE PENELITAN \\ Pendekatan Penelitian}

Pendekatan yang digunakan dalam penelitian ini adalah pendekatan kuantitatif yaitu pendekatan yang menitik beratkan pada pengujian hipotesis yang disertai dengan studi empiris jurnal sebelumnya sebagai pelengkap untuk mendukung kesimpulan secara matematis atau statistik.

Pendekatan kuantitatif diambil karena melalui pendekatan ini proses penelitian dapat dilakukan secara terstruktur dan menggunakan sampel penelitian dalam jumlah besar yang dianggap dapat 
mewakili populasi yang diteliti, maka hasil yang diperoleh dalam penelitian ini merupakan sesuatu yang bersifat konklusif untuk populasi dari mana sampel tersebut diambil (Malhotra, 2005).

\section{Populasi dan Sampel}

Arikunto (2008) menyatakan bahwa: "Sampel adalah sebagian atau wakil dari populasi yang akan diteliti".Teknik yang digunakan dalam penelitian ini adalah purposive sampling. Definisi metode purposive sampling menurut Sugiyono, (2010) adalah: "Teknik penentuan sampel dengan pertimbangan tertentu".

Sampel dalam penelitian ini dibagi atas 2 responden yang berbeda yaitu 75 responden yang melakukan pembelian online produk baju dan 75 responden yang melakukan pembelian offline untuk produk baju. Adapun kriteria responden yang dipilih adalah:

1. Konsumen berumur lebih dari 18 tahun.

2. Memiliki penghasilan sendiri.

3. Pernah berbelanja baik secara online maupun offline untuk produk baju lebih dari 2 kali dalam setahun terkahir.

\section{Definisi Operasional Variabel}

Variabel dalam Penelitian ini adalah Kepuasan Konsumen yang didefinisikan sebagai dalah tingkat perasaan konsumen setelah membandingkan antara apa yang dia terima dan harapannya. Indikator untuk mengukur kepuasan konsumen meliputi:

1. Kepuasan atas kualitas produk

2. Kepuasan atas kualitas layanan

3. Kepuasan atas emosi

4. Kepuasan atas harga

5. Kepuasan atas biaya

Variabel kepuasan diukur pada kepuasan pada pembelian on line dan kepuasan pada pembelian offline.

Pembelian Online yaitu Membeli produk melalui gedget yang terkoneksi dengan internet (PC, smartphone, dll), dengan mengunjungi website toko online dan melakukan order barang melalui website toko online tersebut.

Pembelian Offline yaitu Suatu cara belanja seperti pada umumnya yang dilakukan banyak orang yaitu dengan membeli langsung produk tersebut ke penjualnya.

Kepuasan Konsumen yaitu Sejauh mana anggapan kinerja produk memenuhi harapan pembeli. Dalam penelitian ini faktor-faktornya adalah sebagai berikut (Lupiyoadi : 2001):
1. Kualitas produk, yaitu pelanggan akan merasa puas bila hasil mereka menunjukkan bahwa produk yang mereka gunakan berkualitas. Indikatornya adalah bahan dari baju, kenyamanan baju saat dipakai, tekstur dan desain dari baju.

2. Kualitas pelayanan, yaitu pelanggan akan merasa puas bila mereka mendapatkan pelayanan yang baik atau sesuai dengan yang diharapkan.Indikatornya adalah ketepatan pelayanan, kecepatan merospon konsumen, keramahan dari admin, umpan balik dari pelayan toko.

3. Emosi, yaitu pelanggan akan merasa bangga dan mendapatkan keyakinan bahwa orang lain akan kagum terhadap dia bila menggunakan produk dengan merek tertentu yang cenderung mempunyai tingkat kepuasan yang lebih tinggi. Indikatornya adalah konsumen bangga dengan menggunakan label tertentu, konsumen memiliki percaya diri, konsumen merasa pantas menggunakan produk yang dibeli.

4. Harga, yaitu produk yang mempunyai kualitas yang sama tetapi menetapkan harga yang relatif murah akan memberikan nilai yang lebih tinggi kepada pelanggan. Indikatornya adalah kesesuaian harga dengan kualitas produk, harga yang terjangkau bagi pelanggan.

5. Biaya, yaitu pelanggan yang tidak perlu mengeluarkan biaya tambahan atau tidak perlu membuang waktu untuk mendapatkan suatu produk tersebut. Indikatornya adalah biaya ekpedisi dalam pengiriman barang, adanya COD yaitu bayar ditempat tujuan, free ongkir melalui aplikasi marketplace.

\section{Jenis Data}

Jenis data yang digunakan dalam penelitian ini adalah:

a. Data Kualitatif

Merupakan data yang bukan dalam bentuk angka-angka melainkan menggunakan uraian kalimat yang berhubungan dengan masalah penelitian.

b. Data kuantitatif

Merupakan data yang berbentuk angkaangka atau merupakan satuan data yang terukur yang berkaitan dengan masalah penelitian, yaitu berupa jawaban kuesioner responden. 


\section{Prosedur Pengumpulan Data \\ Studi Kepustakaan}

Peneliti melakukan studi kepustakaan untuk mendapatkan landasan teoritis melalui studi literatur dari berbagai buku, jurnal dan makalah ilmiah yang ada hubungannya dengan penelitian yang dilakukan.

Studi Lapangan

Peneliti melakukan studi lapangan dengan cara menyebarkan kuesioner pada responden yang termasuk dalam kriteria penelitian.

\section{Teknik Analisis data}

\section{Uji Validitas dan Reliabilitas}

Untuk mengetahui kualitas suatu kuesioner maka diperlukan suatu pengujian validitas dan reliabilitas meskipun instrumen atau kuesioner yang digunakan dalam penelitian ini diadopsi dari literatur ataupun hasil penelitian terdahulu menunjukkan tingkat validitas dan reliabilitas yang bisa diterima.

Pengujian validitas dan reliabilitas ini penting untuk dilakukan karena meskipun instrumen tersebut telah dinyatakan valid dan reliabel di berbagai penelitian sebelumnya namun dikuatirkan apabila instrumen ini diterapkan dalam kondisi yang berbeda akan memberikan hasil yang berbeda pula.

\section{Uji Validitas}

Uji validitas digunakan untuk mengukur valid atau tidaknya suatu kuesioner. Suatu kuesioner dikatakan valid jika pertanyaan pada kuesioner mampu mengungkapkan sesuatu yang akan diukur oleh kuesioner tersebut (Ghozali, 2006). Suatu instrumen yang valid mempunyai validitas tinggi, sebaliknya instrumen yang kurang valid berarti memiliki validitas yang rendah. Instrumen dikatakan valid apabila mampu mengukur yang diingin serta dapat mengungkapkan data dari validitas yang diteliti secara tepat. Pengujian ini dilakukan dengan menggunakan pearson correlation, pedoman suatu model dikatakan valid jika tingkat signifikasinya dibawah 0,05 maka butir pertanyaan tersebut dapat dikatakan valid.

\section{Uji Reliabilitas}

Uji reliabilitas (konsistensi dan kestabilan alat ukur) dilakukan untuk mengetahui sejauh mana konsistensi alat ukur dalam memberikan hasil pengukuran. Pengukuran reliabilitas yang digunakan adalah cronbach alpha. Jika cronbach alpha > 0,6 maka konstruk tersebut reliable (Wiratna : 2014), sehingga bisa dikatakan bahwa responden menunjukkan konsistensi dalam memberikan jawaban pada masing-masing indikator kuesioner.

\section{Uji hipotesis Statistik}

Untuk memperoleh gambaran tentang karakterisitik, maka dilakukan deskripsi data untuk variabel demografi. Sedangkan untuk menguji kuesioner dalam penelitian ini harus memenuhi dua syarat penting yang berlaku pada sebuah angket yaitu valid dan reliable, untuk itu digunakan uji validitas dan reliabilitas, dan untuk menjawab hipotesis yang diajukan dalam penelitian ini menggunakan alat statistic Independent T Test.

\section{PEMBAHASAN}

Data yang diperoleh menggunakan skor mulai angka 1 sampai 5 (skala likert) yang dipakai untuk mengukur atau melihat tanggapan responden terhadap kepuasan konsumen dimana tanggapan responden terhadap setiap variabel akan dimasukkan pada rentang skala sebagai berikut:

Tanggapan Responden terhadap Variabel kepuasan konsumen

Item-item pernyataan dan tanggapan responden dapat diketahui sebagai berikut:

\section{Tabel 1}

\section{Tanggapan Responden terhadap Variabel Kepuasan Konsumen}

\begin{tabular}{|c|c|c|c|c|c|c|c|}
\hline \multirow{2}{*}{ No } & \multirow{2}{*}{ Pernyataan } & \multicolumn{5}{|c|}{ Tanggapan } & \multirow{2}{*}{ Rata-rata } \\
\hline & & 1 & 2 & 3 & 4 & 5 & \\
\hline 1 & Kualitas produk & 0 & 1 & 23 & 61 & 65 & 4,18 \\
\hline 2 & Kualitas layanan & 0 & 0 & 29 & 59 & 62 & 4,07 \\
\hline 3 & Emosi & 0 & 2 & 21 & 70 & 57 & 4,21 \\
\hline 4 & Harga & 0 & 0 & 26 & 70 & 54 & 4,27 \\
\hline 5 & Biaya & 0 & 0 & 34 & 71 & 45 & 4,22 \\
\hline
\end{tabular}

Sumber: Data primer yang diolah 
Berdasarkan dari Tabel 1 di atas, dapat diketahui bahwa sebagian besar responden ratarata memberikan tanggapan puas terhadap kualitas produk, kualitas layanan, emosi, harga dan biaya.

\section{Uji Kualitas Data}

Berdasarkan Tabel 2 terlihat bahwa semua butir pernyataan yang mengukur variabel kepuasan konsumen, keseluruhan item pernyataan dinyatakan valid. Hal ini terjadi karena keseluruhan item pernyataan menghasilkan nilai signifikansi $\leq 0,05$.

\section{Tabel 2}

Hasil Uji Validitas

\begin{tabular}{ccccc}
\hline Variabel & $\begin{array}{c}\text { Pernyata } \\
\text { an }\end{array}$ & $\begin{array}{c}\text { Pearson } \\
\text { Correlation }\end{array}$ & Sig. & $\begin{array}{c}\text { Keterang } \\
\text { an }\end{array}$ \\
\hline Kepuasan & $\mathrm{X}_{1 \cdot 1}$ & 0,713 & 0,000 & Valid \\
konsumen & $\mathrm{X}_{1 \cdot 2}$ & 0,783 & 0,000 & Valid \\
& $\mathrm{X}_{1 \cdot 3}$ & 0,788 & 0,000 & Valid \\
& $\mathrm{X}_{1 \cdot 4}$ & 0,715 & 0,000 & Valid \\
& $\mathrm{X}_{1 \cdot 5}$ & 0,737 & 0,000 & Valid \\
\hline
\end{tabular}

Sumber: Data primer yang diolah

\section{Uji Reliabilitas}

\section{Tabel 3}

HasilUji Reliabilitas

\begin{tabular}{lcc}
\hline \multicolumn{1}{c}{ Variabel } & $\begin{array}{c}\text { Cronbach } \\
\text { Alpha }\end{array}$ & Keterangan \\
\hline $\begin{array}{l}\text { Kepuasan } \\
\text { konsumen }\end{array}$ & 0,802 & Reliabel \\
\hline
\end{tabular}

Sumber: Data primer yang diolah

Tabel 3 menunjukkan nilai cronbach's alpha atas kepuasan konsumenlebih besar dari 0,6. Hal ini menunjukkan bahwa setiap item pernyataan yang digunakan akan mampu memperoleh data yang konsisten yang berarti bila pernyataan itu diajukan kembali akan diperoleh jawaban yang relatif sama dengan jawaban sebelumnya.

\section{Tabel 4}

\section{Perbandingan Hasil Uji Statistik Pada} Kualitas Produk

\begin{tabular}{lcccc}
\hline & $\mathbf{N}$ & Mean & $\begin{array}{c}\text { Nilai uji } \\
\mathbf{t}\end{array}$ & Sig \\
\cline { 1 - 3 } online & 75 & 3,933 & 4,677 & 0,000 \\
\cline { 1 - 3 } offline & 75 & 4,440 & & \\
\hline
\end{tabular}

Sumber: Data primer yang diolah

Hasil uji statistik dengan uji independent sample $t$ test Tabel 4 menunjukkan bahwa ada perbedaan kepuasan tentang kualitas produk pada pembelian online dan offline produk baju di Surabaya, terbukti dengan nilai signifikansi sebesar $0,000<0,05$.

Hasil uji statistik dengan uji independent sample $t$ test menunjukkan bahwa ada perbedaan kepuasan tentang kualitas pelayanan pada pembelian online dan offline produk baju di Surabaya, terbukti dengan nilai signifikansi sebesar $0,000<0,05$.

Hasil uji statistik dengan uji independent sample $\mathrm{t}$ test menunjukkan bahwa ada perbedaan kepuasan tentang harga pada pembelian online dan offline produk baju di Surabaya, terbukti dengan nilai signifikansi sebesar $0,008<0,05$.

Tabel 5

\begin{tabular}{ccccc}
\multicolumn{5}{c}{ Perbandingan Hasil Uji Statistik Pada } \\
Kualitas Pelayanan
\end{tabular}

Sumber: Data primer yang diolah

Tabel 6

\begin{tabular}{lcccc}
\multicolumn{5}{c}{ Perbandingan Hasil Uji Statistik Pada } \\
Emosi
\end{tabular}

Sumber: Data primer yang diolah

Hasil uji statistik dengan uji independent sample t test menunjukkan bahwa ada perbedaan kepuasan tentang emosi pada pembelian online dan offlineproduk baju di Surabaya, terbukti dengan nilai signifikansi sebesar $0,003<0,05$.

Tabel 7

Perbandingan Hasil Uji Statistik Harga

\begin{tabular}{lllll}
\hline & N & Mean & $\begin{array}{c}\text { Nilai } \\
\text { uji t }\end{array}$ & Sig \\
\hline online & 75 & 4,107 & 2,708 & 0,008 \\
\hline offline & 75 & 4,427 & & \\
\hline
\end{tabular}

Sumber: Data primer yang diolah

Tabel 8

\begin{tabular}{lcccc}
\multicolumn{6}{l}{ Perbandingan Hasil Uji Statistik Biaya } \\
\hline & N & Mean & $\begin{array}{c}\text { Nilai } \\
\text { uji t }\end{array}$ & Sig \\
\hline online & 75 & 4,080 & 2,321 & 0,022 \\
\hline offline & 75 & 4,360 & & \\
\cline { 1 - 3 }
\end{tabular}

Sumber: Data primer yang diolah 
Hasil uji statistik dengan uji independent sample $\mathrm{t}$ test menunjukkan bahwa ada perbedaan kepuasan tentang biaya pada pembelian online dan offlineproduk baju di Surabaya, terbukti dengan nilai signifikansi sebesar $0,022<0,05$.

\section{Tabel 9}

$\begin{gathered}\text { Perbandingan Hasil Uji Statistik Kepuasan } \\
\text { Konsumen }\end{gathered}$
\begin{tabular}{lcccc} 
& N & Mean & $\begin{array}{c}\text { Nilai } \\
\text { uji t }\end{array}$ & Sig \\
\hline online & 75 & 3,997 & 4,677 & 0,000 \\
\hline offline & 75 & 4,387 & 467 & \\
\hline
\end{tabular}

Sumber: Data primer yang diolah

Hasil uji statistik dengan uji independent sample $t$ test menunjukkan bahwa ada perbedaan kepuasan konsumen pada pembelian online dan offlineproduk baju di Surabaya, terbukti dengan signifikansi sebesar $0,000<0,05$.

Ini artinya bahwa tingkat kepuasan konsumen yang membeli produk secara on line berbeda dengan tingkat kepuasan konsumen yang membeli secara off line. Hal ini dapat diperkuat dari hasil mean untuk kepuasan responden online yaitu sebesar 3,997 nilainya lebih rendah dari mean kepuasan responden offline sebesar 4,387. Artinya bahwa kepuasan konsumen membeli secara offline lebih tinggi dari kepuasan konsumen membeli secara online.

\section{Kepuasan konsumen pada kualitas produk}

Produk yang dijual secara offline (di toko) dapat dengan mudah di lihat kualitasnya seperti bahan kainnya, tekstur kain, warna yang sesungguhnya dan ukuran baju, hal inilah yang menyebabkan konsumen merasa puas apabila melakukan pembelian langsung ditoko, mereka dapat mencoba baju yang di beli dan secara langsung dapat menilai kualitasnya.

\section{Kepuasan konsumen terhadap kualitas pelayanan}

Jika konsumen melakukan pembelian secara online, membutuhkan waktu menunggu balasann pesan yang tidak terbatas, apakah pesan yang disampaikan oleh konsumen kepada admin online langsung dijawab ataukah tidak, dan ini berbeda sekali jika konsumen melakukan pembelian secara offline ( ditoko). Konsumen offline dapat segera dilayani oleh penjual saat mereka melakukan transaksi, meskipun harus menunggu jika toko ramai, transaksi jual beli tetap dapat langsung di laksanakan pada hari itu juga.

\section{Kepuasan konsumen pada variabel emosi}

Membeli produk baju bermerek di toko tentu memiliki nilai tersendiri bagi konsumen, mereka merasa dirinya akan dihargai jika mendatangi langsung toko yang menjual baju dengan brand tertentu, disinilah letak kepuasan konsumen dalam berbelanja ditoko.

\section{Kepuasan konsumen pada harga}

Konsumen yang melakukan pembelian di toko, dapat langsung membandingkan kualitas barang dengan harga saat itu, sedangkan membeli melalui media online membuat konsumen sulit membandingkan antara harga dengan kualiatas apakah sudah sesuai dengan gambar yang di posting dalam media pemasaran online penjual.

\section{Kepuasan konsumen pada biaya}

Pembelian secara online membutuhkan biaya ekspedisi agar barang dapat dikirimkan penjual ke alamat pembeli, hal tersebut tentu dapat menimbulkan salah satu alasan kenapa konsumen lebih memilih untuk membeli baju langsung ke toko, yang dapat mereka lakukan sembari jalanjalan ke Mall, sehingga bisa tidak perlu mengeluarkan biaya ekspedisi.

Pembelian produk yang dilakukan pelanggan baik secara online maupun offline merupakan sebuah pilihan yang tentunya sudah dipertimbangkan oleh mereka. Berbagai alasanalasan dan faktor yang mempengaruhinya seperti yang sudah dilakukan dalam penelitian ini menunjukkan bahwa kualitas produk, kualitas layanan, emosi, harga dan biaya sangat menentukan kepuasan mereka dalam melakukan pembelian baik secara online maupun offline.

Kepuasan konsumen terkait dengan kualitas produk dalam membeli produk baju secara online dan offline dari hasil penelitian menunjukkan perbedaan yang sangat signifikan, hal tersebut bisa terjadi karena membeli secara online konsumen tidak bisa mengetahui secara pasti bagaimana tentang jenis bahan, tekstur dan kenyamanan baju saat dipakai tentu sulit untuk bisa dirasakan bagi pembeli online, hal tersebut tentu sangat bertolak belakang dengan ketika pembeli datang langsung ke toko sehingga mereka bisa memegang, melihat dengan langsung produk tersebut, bahkan pembeli bisa langsung mencoba produk tersebut.

Kualitas layanan juga sangat menentukan kepuasan pelanggan, dalam penelitian ini menujukkan adanya perbedaan yang sangat signifikan ketika melakukan pembelian secara online dan offline. Konsumen yang membeli secara 
langsung ditoko dan membeli melalui media online, seperti instagram, website, facebook dan marketplace tentu mereka bisa merasakan dan membedakan bagaimana cara admin melayaninya, terkadang transaksi melalui media online membutuhkan kesabaran karena harus menunggu respon lambat dari admin yang juga harus melayani pelanggan yang lain. Dengan lambatnya respon dari admin media online tentu membuat faktor psikis konsumen dalam hal ini sangat mempengaruhi emosi mereka.

Ketika konsumen melakukan pembelian secara online mereka bisa menghemat waktu dalam mencari informasi tentang harga. Membeli barang dengan menggunakan aplikasi seperti market place akan mempermudahkan konsumen untuk mendapatkan barang yang mereka cari dan dengan bisa mengetahui harga dari yang paling mahal sampai dengan yang paling murah, hal tersebut tentu sangat berbeda jika konsumen melakukan pembelian secara offline.

Untuk mengetahui informasi harga dan ketersediaan produk yang mereka cari, harus mendatangi satu-satu toko yang dirasa cocok, sehingga membutuhkan waktu yang cukup lama. Didukung dengan hasil penelitian yang menunjukkan bahwa harga sangat mempengaruhi perbedaan kepuasan konsumen ketika membeli melalui media online dan offline adalah sangat relevan.

Namun ada hal penting yang juga perlu dipertimbangkan adalah faktor biaya yang dalam penelitian ini juga menunjukkan adanya perbedaan kepuasan konsumen dalam membeli baju secara online dan offline. Konsumen membutuhkan pertimbangan yang cukup, jika harus memutuskan untuk membeli secara online maka mereka harus rela menambah biaya yang harus dikeluarkan untuk ongkos jasa ekspedisi barang yang akan dikirim, sedangkan untuk melakukan pembelian secara offline mereka bisa memilih toko terdekat untuk menghindari biaya transport yang harus dikeluarkan.

\section{PENUTUP}

\section{Kesimpulan}

Pada dasarnya belanja online dengan belanja offline memiliki kesamaan yaitu sama-sama membeli suatu produk. Yang membedakan adalah dari segi cara membelinya. Belanja offline adalah suatu cara belanja seperti pada umumnya yang dilakukan banyak orang yaitu dengan cara membeli langsung produk tersebut ke penjualnya. Sedangkan belanja online adalah membeli produk melalui gadget yang terkoneksi ke internet bisa melalui laptop maupun smartphone dengan mengunjungi website toko online dan melakukan order barang atau pemesanan barang melalui website toko online tersebut. Sedangkan pembayarannya bisa transfer bank.

Namun dalam hal belanja online, si pembeli tidak repot harus datang langsung ke tempat sang penjual. Barang yang dipesan langsung diantar ke rumah sang pembeli. Jadi perbedaan belanja offline dengan belanja online terletak dalam hal cara membelinya saja dan tujuannya sama yaitu samasama membeli atau belanja.

Dari hasil penelitian yang sudah dilakukan pada 75 responden yang melakukan pembelian online dan 75 responden yang melakukan pembelian offline untuk produk baju, terdapat perbedaan kepuasan konsumen yang signifikan ketika konsumen melakukan pembelian online dan offline.

Hal ini dapat dilihat dari hasil mean untuk kepuasan responden online yaitu sebesar 3,997 nilainya lebih rendah dari mean kepuasan responden offline sebesar 4,387. Artinya bahwa kepuasan konsumen membeli secara offline lebih tinggi dari kepuasan konsumen membeli secara online.

Adanya perbedaan kepuasan konsumen tersebut banyak faktor yang melatar belakanginya, diantaranya yaitu bahwa dengan membeli offline mengharuskan konsumen datang langsung ke penjual hal tersebut bagi seorang yang sibuk dan tidak mempunyai banyak waktu enggan belanja online. Bagi yang sibuk mereka lebih memilih belanja online. Namun yang perlu diketahui adalah bahwa belanja online dikenai biaya ongkos kirim. Harga barang belum termasuk ongkos kirim. Sedangkan belanja offline tidak ada tambahan ongkos kirim karena si pembeli yang datang langsung. Tapi untuk menuju ke tempat penjual juga harus butuh transportasi.

Demikian juga terhadap kualitas produk yang dibeli melalui offline, secara fisik bisa langsung dilihat dan dipegang teksur produknya, dan ini berbeda jauh ketika konsumen melakukan pembelian secara online, yang mana secara fisik tidak bisa langsung riil produknya, karena konsumen hanya melihat berdasarkan foto atau gambar saja, dan hal tersebut bisa saja membuat kecewa pembeli online, ketika barang yang dikirim tidak sesuai dengan yang diharapkan.

Jadi pada dasarnya membeli secara online atau offline memiliki kelebihan dan kelemahanya, 
semua tergantung pada kebutuhan masing-masing konsumen.

\section{Rekomendasi Untuk Penelitian Selanjutnya}

1. Sebaiknya bagi konsumen untuk yang pertama kalinya akan melakukan pembelian online terhadap online shop tertentu, terlebih dahulu bisa mendapatkan informasi atau referensi dari teman yang sebelumnya sudah melakukan pembelian, sehingga konsumen akan mengetahui kualitas maupun pelayanan dari online shop tersebut.

2. Bagi penjual online atau online shop sebaiknya memberikan keterangan atau informasi yang lengkap terkait dengan diskripsi produk yang dijual, sehingga pembeli bisa memastikan kualitas ataupun keawetan dari produk yang dibeli.

3. Bagi penjual konvensional atau offline shop sebaiknya tetap memperhatikan faktor-faktor yang mempengaruhi kepuasan konsumen dalam berbelanja, sehingga tetap bisa mempertahankan pelanggan, meskipun dalam penelitian ini ditemukan bahwa kepuasan konsumen membeli secara offline lebih tinggi ketimbang kepuasan konsumen membeli secara online.

\section{DAFTAR PUSTAKA}

Assauri, S. (2004). Manajemen Pemasaran (Dasar, Konsep dan Strategi), Jakarta: PT. Grafindo Persada.

Kottler, P. (2000). Marketing Management, Englewood.

Kotler, P., \& Keller, K. L. (2009). Marketing management. 1. vyd. Praha: Grada,.

Malhotra, N. K. (2005). Riset pemasaran pendekatan terapan. Jakarta: Indeks

Lupyoadi, R. (2001). Manajemen Pemasaran Jasa (Teori dan Praktek). Depok: Salemba Empat.

Sugiyono. (2010) Memahami Penelitian Kualitatif. Bandung: ALFABET.

Tjiptono, Fandy. Pemasaran Jasa, 2005, Bayumedia Publishing. 